\title{
PENGARUH IMBANGAN PROTEIN DAN ENERGI TERHADAP EFISIENSI PENGGUNAAN RANSUM PADA DOMBA GARUT BETINA
}

\author{
The Effect of Protein to Energy Ratios on Diet Use Efficiency of Female Garut Sheep
}

\author{
Budi Ayuningsih ${ }^{a}$, Iman Hernaman ${ }^{a}$, Diky Ramdania ${ }^{a}$, Siswoyo $^{b}$ \\ ${ }^{\text {a} F a c u l t y ~ o f ~ A n i m a l ~ H u s b a n d r y, ~ P a d j a d j a r a n ~ U n i v e r s i t y ~}$ \\ Hegarmanah, Jatinangor, Sumedang Regency, West Java (45363) \\ bUPTD Balai Pengembangan dan Perbibitan Ternak Domba dan Kambing Margawati \\ Margawati Km. 7, Sukanegla, Garut Kota, Garut (44113) \\ E-mail : budiayuningsih@gmail.com
}

\begin{abstract}
This research aimed to study the effect of protein and energy on Diet Use Efficiency of female Garut sheep. Four different treatments diets of different protein to TDN (energy) ration such as $R 1=11.53 \%: 63.13 \% ; R 2=10.78 \%: 70.06 \% ; R 3=13.54 \%: 63.18 \%$; and $R 4=13.67 \%: 69.18 \%$ were allocated to 20 heads of female Garut sheep with 7-8 months old and average body weight $15.72 \pm 1.33 \mathrm{~kg}$. Completely randomized design was used and collected data was analyzed with Duncan's test. The results showed that highest diet use efficiency and protein consumption $(P<0.05)$ were seen in $R 4$ treatment, $13.09 \%$ and $94.04 \mathrm{~g} /$ day. Meanwhile, TDN consumption did not have any different among $R 4$ (480.23 g/day), $R 2$ (474.80 g/day), and $R 1$ (446.77 g/day) but they were higher $(P<0.05)$ than $R 3$ (370.87 g/day). In other hand, TDN digestibility of $R 2$ and $R 3$ were higher than $R 1$ and $R 3$. In conclusion, protein to TDN ratio of 13.67\%:69.18\% resulted highest diet use efficiency.
\end{abstract}

Keywords: Female Garut Sheep, Digestibility, Protein, Total Digestible Nutrient

\section{PENDAHULUAN}

Domba Garut merupakan salah satu Sumber Daya Genetik Ternak (SDGT) khas Jawa Barat. Penyebaran Domba Garut di Indonesia tidak terlepas dari peranan domba betina. Domba betina memiliki peranan penting sebagai induk yang akan melahirkan anak-anaknya untuk memperbanyak populasi. Anak yang sehat dihasilkan dari induk yang sehat, hal ini terjadi jika lingkungan mendukung. Banyak faktor yang mempengaruhi reproduksi ternak betina diantaranya kondisi tubuh dan nutrisi (Spitzer $e t$ al. 1995). Ternak ruminansia yang mengalami kekurangan protein dan energi berakibat pada kehilangan bobot tubuh dan berdampak pada kegagalan reproduksi (Olson et al., 1999). Oleh karena itu diperlukan keseimbangan protein dan energi (Total Digestible Nutrient/TDN) dalam ransum.

Laju degradasi karbohidrat sebagai sumber energi dan protein pakan di dalam rumen dapat memberikan pengaruh yang besar terhadap produk akhir fermentasi dan performan ternak (Russel et al., 1992). Apabila substansi N terdegradasi lebih cepat dibandingkan dengan sumber energi (TDN), maka amonia hasil degradasi senyawa $\mathrm{N}$ akan ditransfer ke organ hati, dan selanjutnya didaur-ulang ke saluran pencernaan (sebagian kecil) dan sebagian besar hilang bersama sekresi urin. Sebaliknya, apabila jumlah energi tersedia melampaui ketersediaan $\mathrm{N}$, maka pertumbuhan mikroba dan efisiensi fermentasi rumen menurun. Jika degradasi pakan lambat, konsumsi akan tertekan dan sejumlah nutrien tidak dapat diermentasi secara maksimal dalam rumen (Ginting, 2005). Hal ini akan menghambat asupan nutrient bagi induk semang yang lebih lanjut berpengaruh terhadap efisiensi penggunaan ransum. Penelitian ini bertujuan untuk mempelajari pengaruh imbangan protein dan energi terhadap efisiensi penggunaan ransum domba Garut betina.

\section{MATERI DAN METODE}

Penelitian dilaksanakan di UPTD Balai Pengembangan dan Perbibitan Ternak Domba dan Kambing Margawati Kabupaten Garut, Dinas Ketahanan Pangan dan Peternakan Provinsi Jawa Barat. Dua puluh ekor domba Garut betina dialokasikan secara acak ke dalam 4 macam ransum perlakuan (Tabel 1) dan ditempatkan ke dalam kandang individu. Domba tersebut berumur 7-8 bulan dengan bobot badan $15,72 \pm 1,33 \mathrm{~kg}$. 
Tabel 1. Bahan Pakan dan Komposisi Ransum Percobaan

\begin{tabular}{lcccc}
\multicolumn{1}{c}{ Bahan Pakan } & R1 & R2 & R3 & R4 \\
\hline Rumput gajah (\%) & 60,00 & 40,00 & 60,00 & 40,00 \\
Bungkil kedele (\%) & 0,50 & 0,50 & 4,58 & 9,10 \\
Bungkil kelapa (\%) & 13,29 & 28,30 & 12,92 & 21,17 \\
Jagung (\%) & 0,50 & 0,50 & 0,50 & 0,50 \\
Dedak padi (\%) & 9,65 & 0,50 & 8,73 & 0,50 \\
Pollard (\%) & 9,56 & 0,50 & 10.77 & 0,50 \\
Onggok (\%) & 4,49 & 27,70 & 1,00 & 24,24 \\
Molases (\%) & 1,00 & 1,00 & 1,00 & 1,00 \\
Mineral mix (\%) & 1,00 & 1,00 & 1,00 & 1,00 \\
Kandungan nutrien bahan pakan & & & & \\
- Abu (\%) & 11,93 & 9,49 & 11,94 & 9,55 \\
- Protein kasar (\%) & 11,53 & 10,78 & 13,54 & 13,67 \\
- Lemak kasar (\%) & 4,62 & 4,13 & 4,51 & 3,50 \\
- Serat kasar (\%) & 23,79 & 19,36 & 23,58 & 18,81 \\
- Bahan ekstrak tanpa nitrogen & & & & \\
(\%) & 46,69 & 55,18 & 45,02 & 53,41 \\
- Kalsium (\%) & 0,47 & 0,41 & 0,47 & 0,42 \\
- Fosfor (\%) & 0,51 & 0,41 & 0,52 & 0,43 \\
- Total digestible nutrient (\%) & 63,13 & 70,06 & 63,18 & 69,81 \\
\hline
\end{tabular}

Ransum percobaan terdiri atas rumput Gajah dan konsentrat. Konsentrat tersusun dari berbagai bahan pakan seperti bungkil kedelai, bungkil kelapa, jagung, dedak padi, polard, onggok, molases, dan mineral mix. Pada awal penelitian masing masing domba diberi obat cacing dengan dosis $0,4 \mathrm{~mL} / \mathrm{kg}$ bobot badan. Selama 4 minggu, domba tersebut diadaptasikan dengan ransum percobaan dan selanjutnya dicatat konsumsi bahan kering dan pertambahan bobot badan selama 12 minggu untuk menghitung efisiensi penggunaan ransum (Ekawati et al., 2014). Pada 1 minggu menjelang berakhirnya penelitian diambil sampel feses untuk menghitung kecernaan TDN. Analisis kandungan nutrien sampel menggunakan metode AOAC (2005).

Rumus efisiensi penggunaan ransum adalah sebagai berikut :

\section{$\frac{\text { Pertambahan Bobot Badan }}{\text { Konsumsi Bahan Kering Harian }} \times 100 \%$}

Konsumsi protein dan TDN dihitung dengan cara mencatat konsumsi bahan kering harian dan mengkalikannya dengan jumlah protein dan TDN yang terkandung dalam ransum. Kecernaan TDN dihitung dengan menggunakan rumus :

$$
\begin{aligned}
\mathrm{TDN}= & \% \mathrm{SK} \text { dd }(\text { dapat dicerna })+\% \text { BETN dd } \\
& +\% \mathrm{PK} \mathrm{dd}+2,25 \% \mathrm{LK} \mathrm{dd}
\end{aligned}
$$

Penelitian dilakukan secara eksperimental menggunakan rancangan acak lengkap, data yang terkumpul dianalisis dengan uji Duncan (Steel dan Torrie, 1995).

Tabel 2. Rerata Efisiensi Penggunaan Ransum, Konsumsi Protein dan Konsumsi TDN Domba Garut Betina

\begin{tabular}{lrrrr}
\hline \multicolumn{1}{c}{ Peubah } & R1 & \multicolumn{1}{c}{ R2 } & \multicolumn{1}{c}{ R3 } & \multicolumn{1}{c}{ R4 } \\
\hline Efisiensi Penggunaan Ransum (\%) & $8,79^{\mathrm{a}}$ & $10,21^{\mathrm{a}}$ & $8,18^{\mathrm{a}}$ & $13,09^{\mathrm{b}}$ \\
Konsumsi Protein Harian (g/hari) & $81,60^{\mathrm{b}}$ & $73,06^{\mathrm{a}}$ & $79,48^{\mathrm{ab}}$ & $94,04^{\mathrm{c}}$ \\
Konsumsi TDN harian (g/hari) & $446,77^{\mathrm{b}}$ & $474,80^{\mathrm{b}}$ & $370,87^{\mathrm{a}}$ & $480,23^{\mathrm{b}}$ \\
Kecernaan TDN (\%) & $416,81^{\mathrm{ab}}$ & $438,3^{\mathrm{b}}$ & $407,82^{\mathrm{a}}$ & $424,80^{\mathrm{ab}}$ \\
\hline
\end{tabular}

Keterangan : Superskrip yang berbeda ke arah baris menunjukkan berbeda nyata $(\mathrm{P}<0,05)$

\section{HASIL DAN PEMBAHASAN}

Setelah pemeliharaan selama 12 minggu pencatatan data, diperoleh data efisiensi penggunaan ransum, konsumsi protein, energi (TDN) dan kecernaan TDN yang disajikan pada Tabel 2. Tabel tersebut menunjukan bahwa efisiensi penggunaan ransum dan konsumsi protein nyata $(\mathrm{P}<0,05)$ paling tinggi diperoleh pada perlakuan R4. Perlakuan R4 juga menunjukan rataan konsumsi energi lebih tinggi diantara perlakuan meskipun tidak berbeda nyata dengan R1 dan R3, sementara itu kecernaan TDN pada perlakuan R2 dan R4 nyata lebih tinggi 
$(\mathrm{P}<0,05)$ dibandingkan dengan perlakuan $\mathrm{R} 1$ dan R3. Pada perlakuan R4 memiliki tingkat efsiensi penggunaan ransum yang paling tinggi diduga karena terkait dengan konsumsi protein dan energi yang tinggi sebagai akibat kandungan protein dan TDN yang tinggi disertai dengan kecernaan TDN yang juga tinggi (Tabel 1 dan 2).

Miikroba rumen untuk berkembang dan beraktifitas dalam mencerna membutuhkan $\mathrm{N}$ yang tersedia dalam pakan. Protein tinggi dalam pakan mencerminkan ketersediaan $\mathrm{N}$ yang tinggi. Oktarina et al. (2004) menyatakan bahwa peningkatan kadar protein dalam pakan akan meningkatkan laju perkembangbiakan dan populasi mikrobia rumen sehingga kemampuan mencerna pakan menjadi lebih besar. Daya cerna yang tinggi berakibat pada asupan nutrien yang lebih banyak yang akan digunakan untuk pertumbuhan bagi domba. Namun demikian penambahan protein tidak diimbangi dengan pemberian TDN yang cukup tidak akan berakibat pada peningkatan kecernaan.

Penelitian ini sejalan dengan pernyataan Soto et al. (1994) bahwa penambahan sumber protein tidak dapat menstimulasi pertumbuhan mikroba rumen tanpa adanya suplementasi karbohidrat terlarut. Karbohidrat terlarut termasuk ke dalam fraksi karbohidrat non struktural pada Bahan Ekstrak Tanpa Nitrogen (BETN). BETN ini merupakan komponen nutrien terbesar dalam TDN, dimana pada perlakuan R4 kandungan BETN sebesar 53,41\% lebih tinggi dibandingkan dengan perlakuan lainnya, kecuali R2. Tingginya suplai $\mathrm{N}$ dan diimbangi dengan TDN yang tinggi, maka terjadi keseimbangan protein dan energi yang berdampak pada kecernaan dan efisiensi penggunaan ransum yang lebih tinggi. Semakin tinggi nilai efisiensi pakan berarti semakin tinggi pula tingkat pemanfaatan pakan untuk digunakan menaikkan bobot badan ternak. Menurut Mathius et al. (2001) bahwa nilai efisiensi pakan pada domba berkisar antara 6,78-13,2\%. Muktiani et al. (2013) mendapatkan PBBH domba yang diberi silase limbah sayur dengan penambahan mineral berkisar antara 90-138 $\mathrm{g} /$ hari dengan efisiensi pakan berkisar antara $17,33-22,09 \%$.

Kecernaan TDN pada perlakuan R4 memiliki nilai yang lebih tinggi dibandingkan dengan R1 dan R3 namun sama dengan R2. Kondisi ini sebagai akibat dari ransum R4 dan R2 memiliki tingkat BETN yang tinggi dengan serat kasar yang rendah dibandingkan dengan perlakuan lainnya. Serat kasar yang tinggi akan menganggu kecernaan (Despal, 2000), sedangkan BETN lebih mudah untuk dicerna (Astuti et al., 2009). Kecernaan TDN yang tinggi pada perlakuan R4 mendukung peningkatan efisiensinsi ransum.

\section{SIMPULAN}

Imbangan protein dan energi pada perbandingan kisaran $13,67 \%$ : $69,18 \%$ menghasilkan tingkat efisiensi penggunaan ransum yang paling baik.

\section{UCAPAN TERIMAKASIH}

Terimakasih disampaikan pada Direktorat Riset, Pengabdian pada Masyarakat, dan Inovasi, Universitas Padjadjaraan yang telah mengalokasikan dana Hibah Internal Universitas Padjadjaran tahun Anggaran 2017 serta pada UPTD Balai Pengembangan dan Perbibitan Ternak Domba dan Kambing Margawati Kabupaten Garut, Dinas Ketahanan Pangan dan Peternakan Provinsi Jawa Barat yang telah mendukung dan memberikan fasilitas penelitian.

\section{DAFTAR PUSTAKA}

AOAC. 2005. Official Methods of Analysis.18th edn. Association of Official Agricultural Chemists. Washington, DC. Astuti, A., A. Agus, dan S. P. S. Budhi. 2009. Pengaruh penggunaan high quality feed supplement terhadap konsumsi dan kecernaan nutrien sapi perah awal laktasi. Bul. Pet. 33: 8187.

Soto, R.C., Muhammed, S.A., Newbold,C.J., Stewart, C.S., and Wallace,R.J. 1996. Influence of peptides, amino acid, and urea on microbial activity in the rumen of sheep receiving grass hay and on the growth of rumen bacteria in-vitro. Animal Feed Science and Technology 49, pp. 151-161

Despal. 2000. Kemampuan komposisi kimia dan kecernaan in vitro dalam mengestimasi kecernaan in vivo. Media Peternakan 23: 84-88.

Ekawati, E., Anis Muktiani dan Sunarso. 2014. Efisiensi dan kecernaan ransum domba yang diberi silase ransum komplit eceng gondok ditambahkan starter Lactobacillus plantarum. Agripet 14(2): 107-114

Ginting, S.P. 2005. Sinkronisasi degradasi protein dan energi dalam rumen untuk memaksimalkan produksi protein mikroba. Wartazoa 15(1)

Mathius, I.W., Yulistiani, D., Wina, E., Haryanto, B., Wilson, A., Thalib, A., 2001. Pemanfaatan energi terlindung untuk 
meningkatkan efisiensi pakan pada domba induk. J. Ilmu Ternak dan Veteriner 6 (1):7-13.

Muktiani, A., Achmadi, J., Tampoebolon, B.I.M., Setyorini, R., 2013. Pemberian silase limbah sayuran yang disuplementasi dengan mineral dan alginat sebagai pakan domba. J. Ilmu dan Teknologi Peternakan 2 (3):144-151.

Oktarina, K., E. Rianto, R. Adiwinarti, dan A Purnomoadi. 2004. Retensi protein pada Domba Ekor Tipis jantan yang mendapat pakan penguat dedak padi dengan aras yang berbeda. J. Pengembangan Peternakan Tropis Spec. Ed. 1: 110-115

Olson, P.A. D.R. Brink, D.T. Hickok, M.P. Carlson, N.R. Schneider, G.H. Deutscher , D.C. Adams, D.J. Colburn, and A.B. Johnson. 1999. Effects of supplements of organics and inorganics combinations of
Copper, Cobalt, Manganese, and zinc above nutrient requirement levels on pospartum two-year-olds cows. J. Anim. Sci. 77: 522-532.

Russel, J .B., J. D. O'connors, D. G. Fox, P. J. Van Soest dan C.J. Sniffen . 1992. A net carbohydrate and protein system for evaluating cattle diets : 1 . Ruminal fermentation. J. Anim. Sci. 70: 3551-3561

Spitzer, J.C, D.J. Morrison, R.P. Wattemann and L.C. Faulkner. 1995. Reproductive responses and calf birth and weaning weights as affected by body condition at parturition and postpartum weight gain in primiparous beef cows. J. Anim.Sci. 73: 1251-1257.

Steel, R.G.D. dan Torrie, J.H., 1995. Prinsip dan Prosedur Statistika Suatu Pendekatan Biometrik. Cetakan ke-4. PT. Gramedia Pustaka Utama, Jakarta. 